\title{
PEMBUATAN SABUN DI DESA TORONGREJO KOTA BATU
}

\author{
Sumanto $^{1)}$, Iftitah Ruwana ${ }^{2)}$, Basuki Widodo ${ }^{3)}$, Nyoman Sudiasa ${ }^{4)}$ \\ ${ }^{1,2)}$ Prodi Teknik Industri, Fakultas Teknologi Industri, Institut Teknologi Nasional Malang \\ ${ }^{3)}$ Prodi Teknik Mesin, Fakultas Teknologi Industri, Institut Teknologi Nasional Malang \\ ${ }^{4)}$ Prodi Teknik Sipil, Fakultas Teknik Sipil dan Perencanan, Institut Teknologi Nasional Malang
}

\begin{abstract}
Abstrak, Desa Torongrejo juga mempunyai Lembaga Pemberdayaan Masyarakat Desa (LPMD) yang mencoba membantu untuk meningkatkan kemandirian masyarakat Desa dan meningkatkan ekonomi masyarakat desa. Dalam pelaksanaannya, LPMD bersinergi dengan kelompok Pendidikan Kesejahteraan Keluarga (PKK) yang dipimpin oleh isteri dari Kepala Desa. Kegiatan-kegiatan yang dilakukan oleh ibu-ibu PKK kebanyakan yang berkaitan dengan peningkatan keterampilan-keterampilan. Dalam rangka meningkatkan kemampuan ibu-ibu dalam membuat sabun mandi, maka Tim Pengabdian Masyarakat Jurusan Teknik Industri S1 ITN Malang memfasilitasi pelatihan di Desa Torongrejo Kota Batu. Kegiatan ini merupakan upaya untuk meningkatkan taraf hidup masyarakat Desa Torongrejo Kota Batu yang diharapkan dapat menjadi kenyataan dengan kemandirian ekonomi. Kegiatan pelatihan pembuatan sabun diikuti oleh 25 (dua puluh lima) peserta yang merupakan kaderkader penggerak PKK Desa Torongrejo Batu. Pelatihan dilaksanakan pada tanggal 6 September 2016. Ibu-ibu peserta sangat antusias dalam mengikuti kegitaan ini. Di samping itu mereka merasa mendapatkan ilmu dan pengetahuan baru tentang sabun, sehingga banyak yang akan memproduksi sendiri sabun tersebut. Ditinjau dari dari segi ekonomi, masing-masing bahan utama sebanyak 200 gram dapat dibeli dengan harga Rp. 5.600, dan dapat dihasilkan sebanyak 1,7 liter sabun cair. Jika dibandingkan dengan sabun sejenis yang dibeli di super market, maka sabun buatan sendiri harganya jauh lebih murah. Kalaupun hasilnya mau dipasarkan atau dijual dengan harga Rp. 10.000,- maka diperoleh keuntungan Rp. 4.400,- per 1,5 liter.
\end{abstract}

Kata Kunci: Sabun, Desa Torongrejo

\section{PENDAHULUAN}

Desa Torongrejo secara administrasi pemerintahan merupakan bagian dari Kecamatan Junrejo Kota Batu. Desa Torongrejo berbatasan langsung dengan Desa Beji dan Mojorejo di sebelah selatan, di sebelah timur berbatasan dengan Desa Pendem, di sebelah utara berbatasan dengan Desa Giripurno dan Desa Pandarejo dan di sebelah barat berbatasan dengan desa Temas. Mayoritas pekerjaan masyarakat Desa Torongrejo adalah petani.

Desa Torongrejo juga mempunyai Lembaga Pemberdayaan Masyarakat Desa (LPMD) yang mencoba membantu untuk meningkatkan kemandirian masyarakat Desa dan meningkatkan ekonomi masyarakat desa. Dalam pelaksanaannya, LPMD bersinergi dengan kelompok Pendidikan Kesejahteraan Keluarga (PKK) yang dipimpin oleh isteri dari Kepala Desa. Kegiatan-kegiatan yang dilakukan oleh ibu-ibu PKK kebanyakan yang berkaitan dengan peningkatan keterampilan-keterampilan. Dalam rangka meningkatkan kemampuan ibuibu dalam membuat sanun mandi, maka Tim Pengabdian Masyarakat Jurusan Teknik Industri S1 ITN Malang melaksanakan pengabdian masyarakat di Desa Torongrejo Kota Batu.

Tujuan diadakannya pelatihan ini adalah membekali warga Desa Torongrejo Kota Batu pengetahuan tentang sabun dan membekali warga masyarakat Desa Torongrejo keterampilan membuat sabun cuci.

\section{Sabun}

Sabun yang berasal dari bahasa India/Hindi साबुन adalah surfaktan yang digunakan dengan air untuk mencuci dan membersihkan. Sabun biasanya berbentuk padatan tercetak yang disebut batang. Tetapi sekarang sudah banyak sabun cair yang diproduksi baik untuk sabun mandi maupun sabun cuci peralatan atau sabun cuci pakaian. Penggunaan sabun cair juga telah telah meluas, terutama pada sarana- sarana publik. Jika diterapkan pada suatu permukaan, air bersabun secara efektif mengikat partikel dalam suspensi mudah dibawa oleh air bersih. Di negara berkembang, deterjen sintetik telah menggantikan sabun sebagai alat bantu mencuci atau membersihkan.

Banyak sabun merupakan campuran garam natrium atau kalium dari asam lemak 
yang dapat diturunkan dari minyak atau lemak dengan direaksikan dengan alkali (seperti natrium atau kalium hidroksida) pada suhu 80 $100{ }^{\circ} \mathrm{C}$ melalui suatu proses yang dikenal dengan saponifikasi. Lemak akan terhidrolisis oleh basa, menghasilkan gliserol dan sabun mentah. Secara tradisional, alkali yang digunakan adalah kalium yang dihasilkan dari pembakaran tumbuhan, atau dari arang kayu. Sabun dapat dibuat pula dari minyak tumbuhan, seperti minyak zaitun.

Seiring berkembangnya zaman, sabun sebagai produk perawatan diri memiliki berbagai variasi dan warna. Salah satunya adalah sabun transparan. Sabun ini memiliki sifat layaknya sabun mandi lainnya namun berwarnatransparan. Prinsip dari pembuatan sabun transparan adalah pencampuran massa sabun dalam bahan etanol kemudian dipanaskan dengan pemanasan lembut dan ditambahkan bahan lain yang memiliki fungsi tertentu. Yang menentukan transparansi produk salah satunya adalah humektan yang bersifat higroskopis sehingga mempengaruhi transparansi produk. Agen pembentuk transparan lainnya adalah gliserin, sukrosa, dan beberapa bahan lain.

\section{Pembuatan Sabun Cuci Baju Cair}

Salah satu hal yang paling menakjubkan dalam kehidupan ini adalah fungsi sabun dalam dunia kebersihan. Tidak banyak yang mengetahui jika sabun secara sederhana dapat dibuat dengan mencampurkan abu (sisa pembakaran tumbuhan) dengan lemak atau minyak (nabati atau hewani). Keajaiban dari sabun tidak terlepas dari fungsi utama dari sabun sebagai zat pencuci adalah sifat surfaktan yang terkandung di dalamnya. Surfaktan merupakan molekul yang memiliki gugus polar yang suka air (hidrofilik) dan gugus non polar yang suka minyak (lipofilik) sekaligus, sehingga dapat mempersatukan campuran yang terdiri dari minyak dan air.

\section{Bahan-bahan Pembuat Sabun Cuci Cair}

Texapon $10 \%$ (misalnya untuk 1 Liter atau $1.000 \mathrm{~mL}$ air memerlukan $100 \mathrm{~mL}$ texapon). Texapn disebut juga SLS (sodium lauril sulfat), sifatnya sama seperti LAS pada detergent dan ABS pada sabun colek. Fungsi dari texapon adalah untuk mengangkat lemak atau zat yang memiliki sifat surfaktan.
1. Camperlan (secukupnya). Camperlan Berfungsi sebagai penambah busa dan

pengental. Camperlan juga merupakan zat yang dapat memaksimalkan kerja texapon.

2. Garam dapur (secukupnya). Garam dapur atau natrium klorida $(\mathrm{NaCl})$ merupakan zat utama yang dapat digunakan untuk mengentalkan sabun yang akan dibuat.

3. Parfum (secukupnya, skala ideal yang dapat digunakan adalah $1 \mathrm{~mL}$ parfum untuk $500 \mathrm{~mL}$ air)

4. Pewarna (secukupnya)

5. Air

\section{Proses Pembuatan Sabun Cuci Cair}

1. Texapon dimasukkan ke dalam wadah lalu tambahkan sejumlah air yang dibutuhkan, aduk sampai rata

2. Camperlan ditambahkan secukupnya, pewangi, dan parfum, aduk sampai rata. Untuk sabun komersil biasanya ditambah propil glikol yaitu zat pengikat parfum agar dapat bertahan lebih lama.

3. Terakhir ditambahkan sedikit demi sedikit garam dapur sampai didapatkan kekentalan yang pas, aduk sampai rata

4. Hasilnya disimpan dalam wadah yang tertutup. Sabun yang diuat dapat bertahan sampai berbulan-bulan. Jika ingin dipasarkan maka perlu ditambahkan EDTA yang dapat menyebabkannya bertahan sampai bertahun-tahun dan mengurangi kesadahan air.

\section{METODE}

Metode kegiatan ini diawali dengan observasi kondisi dan situasi Desa Torongrejo Kota Batu dilajutkan dengan koordinasi dengan pihak-pihak terkait di Desa Torongrejo. Setelah mendapatkan gambaran kondisi di Desa Torongrejo, maka dilakukan persiapanpersiapan untuk melakukan pelatihan pembuatan sabun cuci cair. Setelah dilaksanakan pelatihan dilakukan evaluasi kegiatan.

\section{HASIL DAN PEMBAHASAN}

Kegiatan pelatihan dilaksanakan pada tanggal 6 September 2016 diikuti oleh 25 peserta dari ibu-ibu anggota PKK Desa Torongrejo Kota Batu. 
E-ISSN: 2615-3866

Industri Inovatif - Jurnal Teknik Industri ITN Malang, 29 September 2018

Pembuatan Sabun Di Desa Torongrejo Sumanto / Iftitah / Basuki/ Nyoman
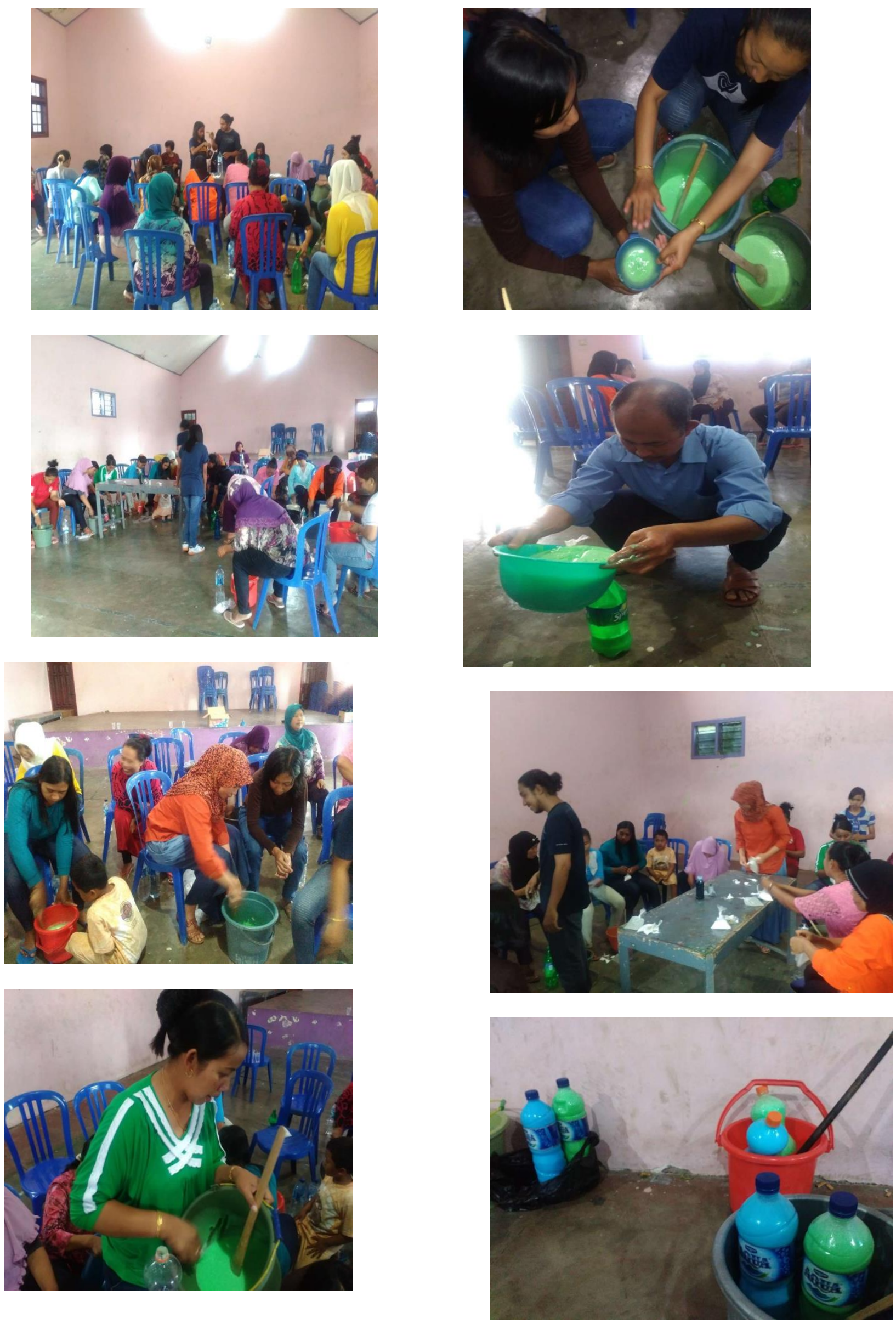


\section{Pembahasan}

Pembuatan sabun (deterjen) yang dilakukan tidak memerlukan keterampilan khusus, tetapi hanya pengetahuan tentang bahan-bahan yang digunakan yang diperlukan. Sementara itu pengetahuan tentang bahanbahan ini bisa diperoleh dari internet. Karena pembuatan sabun cuci ini cukup.mudah maka setiap.peserta pelatihan berkesempatan untuk dapat memproduksinya secara masal. Sabun yang telah berhasil dibuat diuji coba oleh peserta pelatihan dan hasilnya memuaskan menurut pendapat peserta.

Pembuatan sabun ini sangat menguntungkan karena dari masing-masing bahan utama sebanyak 200 gram ( 2 ons) dapat dihasilkan detrjen cair kental sebanyak 1,7 liter baik untuk sabun cuci pakaian cair maupun sabun cair untuk peralatan dapur. Dari jumlah 1,7 liter ini masih dapat diencerkan lagi sesuai dengan selera.

Ditinjau dari dari segi ekonomi, masingmasing bahan utama sebamyak 200 gram dapat dibeli dengan harga Rp. 5.600, dan dapat dihasilkan sebanyak 1,7 liter sabun cair. Jika dibandingkan dengan sabun sejenis yang dibeli di super market, maka sabun buatan sendiri harganya jauh lebih murah. Kalaupun hasilnya mau dipasarkan atau dijual dengan harga Rp. 10.000,- maka kita masih mendapatkan keuntungan Rp. 4.400,- per 1,5 liter.

\section{KESIMPULAN DAN SARAN \\ Kesimpulan}

Hasil pelatihan pembuatan sabun di Desa Torongrejo Kota Batu adalah sebagai berikut:

1. Menurut peserta pelatihan sabun yang dihasilkan dalam pelatihan ini kualitasnya cukup memuaskan.

2. Dari segi ekonomi, dengan membuat sabun sendiri, maka biaya yang dikeluarkan lebih sedikit dibandingkan dengan membeli produk sabun jadi

3. Jika produk yang dihasilkan akan dijual maka jelas akan menghasilkan keuntungan (menambah penghasilan).

\section{Saran}

Berdasarkan hasil pelatihan, dapat disarankan sebagai berikut:

1. Perlu diadakan pelatihan sejenis untuk produk yang berbeda yaitu sabun madi cair dan sabun mandi batangan
2. Untuk produksi sabun yang akan dijual atau dipasarkan jmaka perlu analisis lebih lanjut misalnya analisis pemasaran dan sebagainya

3. Warga menginginkan adanya pelatihan lain.

\section{DAFTAR PUSTAKA}

\section{2014. Profil Desa Torongrejo}

2. http://adevnatural.com/cara-membuat-sabunbatang-transparan- herbal-aroma-terapisendiri-di-rumah-untuk-souvenir-gift-dankecantikan/

3. https://othervisions.wordpress.com/2014/07/ 31/membuat-sabun-sendiri/

4. http://pusataroma.com/blog/cara-membuatsabun-batang-susu-beras- thailand/

5. http://cara-membuatsendiri.blogspot.com/2013/08/caramembuat- sabun-mandi- cair.html 